\title{
The renal and hepatic distribution of Bence Jones proteins depends on glycosylation: a scintigraphic study in rats
}

\footnotetext{
M.J.B.A. Prado ${ }^{1}$, A.L. Nicastri', P.L.A. Costa ${ }^{2}$, T. Rockman ${ }^{3}$, I.L.S. Tersariol ${ }^{4}$, H.B. Nader ${ }^{4}$,

R.T. Barros ${ }^{1}$ and E.B.A. Prado ${ }^{1}$
}

\author{
${ }^{1}$ Laboratório de Fisiopatologia Renal, Faculdade de Medicina, \\ Universidade de São Paulo, 01246-903 São Paulo, SP, Brasil \\ ${ }^{2}$ Serviço de Radioisótopos, Hospital das Clínicas, \\ Universidade de São Paulo, 05403-000 São Paulo, SP, Brasil \\ ${ }^{3}$ Centro de Medicina Nuclear, Universidade de São Paulo, \\ 05403-010 São Paulo, SP, Brasil \\ ${ }^{4}$ Laboratório de Biologia Molecular, Universidade Federal de São Paulo, \\ 04024-900 São Paulo, SP, Brasil
}

\author{
Correspondence \\ E.B.A. Prado \\ Laboratório de Fisiopatologia Renal \\ Faculdade de Medicina, USP \\ Av. Dr. Arnaldo, 455 \\ 3 o andar, Sala 3342 \\ 01246-903 São Paulo, SP \\ Brasil \\ Fax: 55 (011) 883-1693
}

Publication supported by FAPESP.

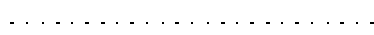

Received September 17, 1996 Accepted May 20, 1997

\begin{abstract}
The aim of the present study was to evaluate renal and liver distribution of two monoclonal immunoglobulin light chains. The chains were purified individually from the urine of patients with multiple myeloma and characterized as lambda light chains with a molecular mass of 28 $\mathrm{kDa}$. They were named BJg (high amount of galactose residues exposed) and BJs (sialic acid residues exposed) on the basis of carbohydrate content. A scintigraphic study was performed on male Wistar rats weighing $250 \mathrm{~g}$ for $60 \mathrm{~min}$ after $i v$ administration of $1 \mathrm{mg}$ of each protein $(7.4 \mathrm{MBq})$, as the intact proteins and also after carbohydrate oxidation. Images were obtained with a Siemens gamma camera with a high-resolution collimator and processed with a MicroDelta system. Hepatic and renal distribution were established and are reported as percent of injected dose. Liver uptake of BJg was significantly higher than liver uptake of BJs $(94.3 v s$ 81.4\%) $(\mathrm{P}<0.05)$. This contributed to its greater removal from the intravascular compartment, and consequently lower kidney accumulation of BJg in comparison to BJs $(5.7 v s 18.6 \%)(\mathrm{P}<0.05)$. After carbohydrate oxidation, there was a decrease in hepatic accumulation of both proteins and consequently a higher renal overload. The tissue distribution of periodate-treated BJg was similar to that of native BJs: 82.7 vs $81.4 \%$ in the liver and 17.3 vs $18.6 \%$ in the kidneys. These observations indicate the important role of sugar residues of Bence Jones proteins for their recognition by specific membrane receptors, which leads to differential tissue accumulation and possible toxicity.
\end{abstract}

Key words

- Bence Jones proteins

- Scintigraphic study

- Multiple myeloma

- Nephrotoxicity 


\section{Introduction}

Multiple myeloma is a disease characterized by abnormal production of monoclonal proteins, with a higher incidence in people older than 50 years. Frequently, large amounts of immunoglobulin light chains are delivered to systemic circulation $(1,2)$. Light chains have a low molecular weight that favors their excretion by glomerular filtration. Many factors contribute to the nephrotoxic potential of these light chains, named Bence Jones proteins (3): degree of polymerization, isotype, isoelectric point and glycosylation. Clinical (4-8) and experimental (9-12) studies have been conducted to elucidate the mechanisms of this toxicity. Bence Jones proteins are highly glycosylated, differing from the pattern of normal secreted immunoglobulins (13). The main organs responsible for their removal from the circulation are the liver and kidney. In the liver, and, to a lesser extent, in the kidneys, there is a significant participation of the endocytic apparatus composed of endocytic membranes, vesicles, early endosomes, pre-lysosomes and lysosomes $(14,15)$. In a review, Bradbury and Bridges (16) focused on the molecular mechanisms involved in regulating protein transport. Membrane internalization and endocytosis of macromolecules are complex processes regulated by many proteins associated with GTP and other intracellular messengers $(17,18)$. The handling of low molecular weight glycoproteins depends on the amount and type of exposed sugar residues. Many investigators have shown that sugar residues interfere with the pattern of tubular reabsorption (19) or liver uptake. Liver sinusoidal cells play an important role in host defense by clearing particulate matter and macromolecules from the circulation (20). Yoshioka et al. (21) studied receptormediated endocytosis of chemically modified glycoproteins by sinusoidal endothelial cells and Kupffer cells in the liver. Hepatic cells have specific receptors for asialoglyco- proteins (22). Endocytosis of plasminogenactivating factor is mediated by mannose receptors on endothelial cells rather than galactose receptors on parenchymal cells (23).

While studying the uptake of Bence Jones proteins by kidney cells, using immunocytochemistry and electron microscopy (24), we developed a protocol to study tissue distribution of Bence Jones proteins in intact animals, using noninvasive techniques. Scintigraphic analysis permits the continuous evaluation of renal and hepatic dynamics and the precise measurement of several functional parameters, thus providing more detailed information. Native Bence Jones proteins were labelled with technetium-99m

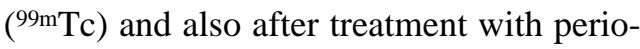
date. In recent years much effort has been invested in developing radiolabelled monoclonal antibodies for diagnostic and therapeutic applications. Because of its excellent physical characteristics, ${ }^{99 \mathrm{~m}} \mathrm{Tc}$ has been used in diagnostic imaging within a few hours of administration. No studies correlating the participation of sugar residues of ${ }^{99 \mathrm{~m}} \mathrm{Tc}-\mathrm{la}-$ belled glycoproteins in liver and hepatic distribution are available. The present study was carried out in order to obtain more information on the pathogenesis of nephrotoxicity.

\section{Material and Methods}

\section{Purification of Bence Jones proteins}

Human Bence Jones proteins (light chains of monoclonal immunoglobulins) were obtained from 2 patients with multiple myeloma from the Nephrology Division, University of São Paulo School of Medicine, and purified individually. Urine was concentrated through a hollow fiber dialysis membrane and Tamm-Horsfall proteins were precipitated with $5 \% \mathrm{NaCl}$. Supernatant proteins were precipitated with $70 \%\left(\mathrm{NH}_{4}\right)_{2} \mathrm{SO}_{4}$. The precipitate was chromatographed on DEAE-Sephacel in $5 \mathrm{mM}$ sodium phosphate 
buffer, $\mathrm{pH}$ 8.0. Both Bence Jones proteins were submitted to SDS-PAGE for molecular weight determination, immunoblotting, and characterization of band specificity (25). The light chain isotype was determined by immunoelectrophoresis (26).

\section{Carbohydrate composition of Bence Jones proteins}

Sialic acid residues were determined as described by Svennerholm (27), without previous hydrolysis. The equation proposed by Spiro (28) was applied to correct for interference from neutral hexoses.

Neutral and basic sugar residues were determined after acid hydrolysis with $4 \mathrm{~N}$ $\mathrm{HCl}$ for $4 \mathrm{~h}$ at $100^{\circ} \mathrm{C}$. The samples were submitted to ion-exchange chromatography on mix-bed type resin. Neutral fractions were eluted in water, resuspended and concentrated to dryness. The samples were resuspended again and submitted to descending chromatography on Whatman paper number one (Whatman Int. Ltd., Maidstone, England) for $20 \mathrm{~h}$ using two organic solvents: ethylacetate/isopropanol/water $(5: 2: 1, \mathrm{v} / \mathrm{v} /$ v) and $1.25 \mathrm{~N}$ ammonium butyrate. Sugar residues were detected with silver reagents in alkaline medium (29) and quantified by densitometry (Shimadzu CS-9000). Ion-exchange chromatography was omitted when basic residues were determined.

\section{Periodate oxidation of carbohydrate content of Bence Jones proteins}

Carbohydrate oxidation was performed according to the method of Spiro (30). Both proteins were treated with $60 \mathrm{mM}$ sodium metaperiodate in $50 \mathrm{mM}$ sodium acetate buffer, $\mathrm{pH} 4.5$, at $4^{\circ} \mathrm{C}$ for $48 \mathrm{~h}$ in the dark. The reaction was monitored by spectrophotometry at $225.5 \mathrm{~nm}$ (31) and interrupted by the addition of glucose $(0.1 \mathrm{M})$. Samples were submitted to SDS-PAGE in order to determine if large modifications of molecu- lar weight had occurred as the result of oxidation.

\section{Labelling of Bence Jones proteins with ${ }^{99 \mathrm{~m}} \mathrm{Tc}$}

Native and oxidized Bence Jones proteins were labelled with ${ }^{99 \mathrm{~m} T c}$ by a direct method $(32,33)$. ${ }^{99 \mathrm{~m}} \mathrm{Tc}$ generator was obtained from the Energetic and Nuclear Research Institute (National Council of Nuclear Engineering, São Paulo). Briefly, $150 \mathrm{mg}$ stannous chloride $\left(\mathrm{SnCl}_{2}\right)$ was dissolved in 5 $\mathrm{ml}$ of $0.1 \mathrm{~N} \mathrm{HCl}$. Fifty $\mu \mathrm{l}$ of this solution was added to a solution of $30 \mathrm{mg} / \mathrm{ml}$ of each protein, the $\mathrm{pH}$ was adjusted to 5.0 and volume was completed to $3 \mathrm{ml}$ with saline. The solution was bubbled with nitrogen.

Labelling of $1 \mathrm{mg}$ of oxidized or native protein with reduced sodium pertechnetate ( ${ }^{99 \mathrm{~m}} \mathrm{Tc}$ ) was allowed to proceed for $15 \mathrm{~min}$. Radiochemical purity was determined by paper chromatography on Whatman number 3 in two solvents, i.e., acetone and $0.9 \% \mathrm{NaCl}$.

\section{Experimental protocol}

${ }^{99 \mathrm{~m} T c-l a b e l l e d ~ B e n c e ~ J o n e s ~ p r o t e i n s ~ w e r e ~}$ injected $i v$ into male Wistar rats, weighing approximately $250 \mathrm{~g}$. One $\mathrm{mg}$ of native and oxidized Bence Jones proteins, with 7.4 MBq activity, was administered to 20 rats (5 rats per protein). A scintigraphic study was performed for $60 \mathrm{~min}$ after administration, and after $24 \mathrm{~h}$ a last recording of tissue distribution was obtained. A Siemens gamma camera with a high-resolution parallel collimator was used and data were processed with a MicroDelta System. Images (128 x 128 matrix) were obtained at 30-s intervals for the first $5 \mathrm{~min}$ and then at 5-min intervals for the next 55 min after injection of the labelled protein. Curves for activity vs time were obtained for organs of interest.

\section{Statistical analysis}

Quantitative results were processed by 
the SIGMA PLOT 5.0 software (Sigma stat Statistical Analysis system version 1.01, Scientific graph system, Jandel Scientific, San Raphael, CA). Data are reported as median and $25-75 \%$ percentiles. Non-parametric tests were performed. Rank analysis of variance was performed by the Kruskal-Wallis test. Dunn's test was applied for multiple comparison among groups, two by two, when a significant difference was observed. The Mann-Whitney test was used for comparison between two groups. The level of significance was set at 0.05 .

\section{Results}

The Bence Jones proteins were identified as lambda light chains on the basis of immunoelectrophoresis. The molecular weights determined by SDS-PAGE (Figure 1) were approximately 28,000 .

Sugar analysis was performed by descending paper chromatography after acid hydroly-

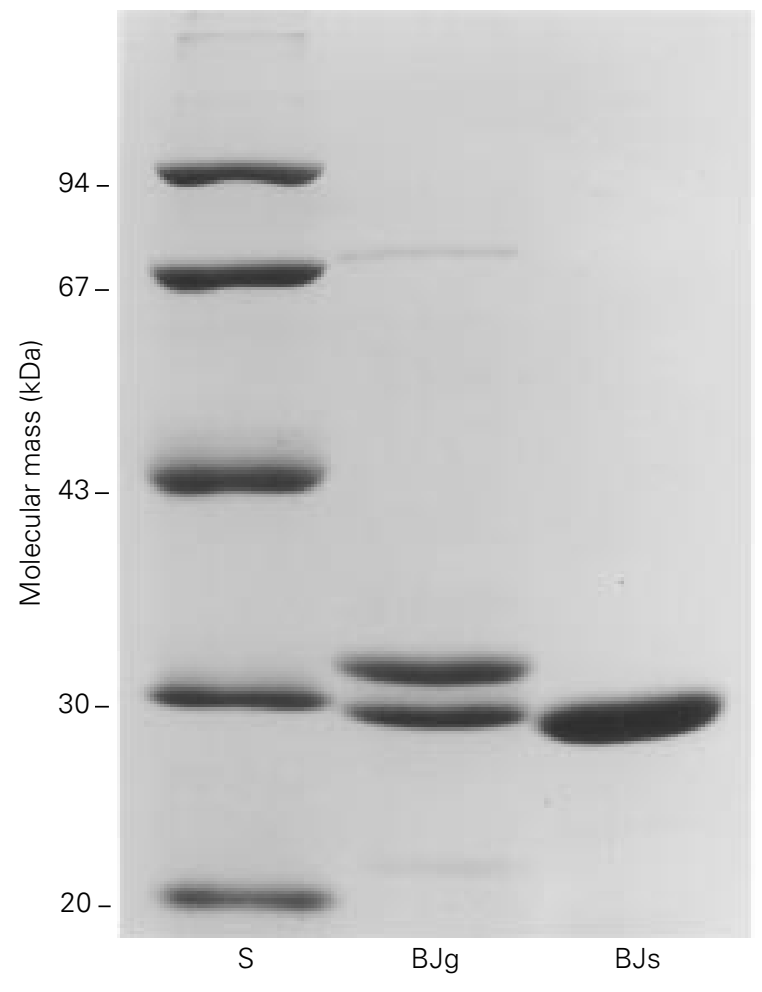

Figure 1 - Determination of the molecular mass of BJg and BJs by SDS-PAGE. S, Molecular mass standards. sis. Quantitative data reported as $\mu \mathrm{g} / \mathrm{mg}$ protein are shown in Table 1. The Bence Jones proteins were named BJg and BJs on the basis of their galactose and sialic acid content. BJg presented larger amounts of galactose in comparison to BJs (28.8vs $4.6 \mu \mathrm{g} / \mathrm{mg}$ protein). BJs presented higher levels of sialic acid $(4.8 v s 0.3 \mu \mathrm{g} / \mathrm{mg})$ and mannose (1.0vs $0.2 \mu \mathrm{g} / \mathrm{mg}$ ) compared to BJg. The oligosaccharides of these Bence Jones proteins were $\mathrm{N}$-linked while O-linked oligosaccharides were not detected. BJg presented a larger amount of carbohydrates than BJs (37.8vs $12.6 \mu \mathrm{g} / \mathrm{mg}$ ) and BJg had a higher percentage of basic and neutral sugars in relation to acid residues (99.2:0.8 vs 61.9:38.1).

The radiochemical purity of Bence Jones proteins labelled with ${ }^{99 \mathrm{~m} T c}$ was approximately $99.9 \%$ as determined by paper chromatography. A representative diagram of ${ }^{99 \mathrm{~m}} \mathrm{Tc}$ decay obtained after infusion of the radiochemical is shown in Figure 2. The tissue distribution of native and periodatetreated proteins is reported as percent of injected dose (Tables 2 and 3).

BJg uptake by the liver was significantly higher than BJs uptake (94.3 vs 81.4\%) $(\mathrm{P}<0.05)$, contributing to a marked BJg removal from the intravascular compartment. Consequently, less BJg was taken up by the kidney in relation to BJs (5.7 vs 18.6\%) $(\mathrm{P}<0.05)$.

After periodate treatment of both Bence Jones proteins there was a significant difference in the tissue distribution of each protein $(\mathrm{P}<0.05)$. There was a reduction in hepatic uptake with a consequent increase in renal distribution of both proteins. Quantitative data showed that there was a decrease in hepatic distribution between native and oxidized BJg (94.3 vs 82.7), and an increase in renal distribution (5.7 vs 17.3\%). The same pattern of hepatic (81.4 vs 71.6\%) and renal distribution (18.6 vs 28.4\%) was observed with BJs before and after sugar oxidation, respectively. Oxidized BJg presented a similar hepatic distribution (82.7 vs $81.4 \%$ ) and consequently a simi- 
lar renal distribution (17.3vs $18.6 \%)$ of native BJs under these conditions.

\section{Discussion}

Many clinical manifestations occur in patients with multiple myeloma, with various degrees of kidney involvement. Some cases are characterized by massive proteinuria and normal renal function, and others by severe renal lesions not related to proteinuria (34). The origin of these differences could be related to systemic characteristics of the patients (35) as well as the physicochemical properties of Bence Jones proteins (11).

The role of carbohydrate content of Bence Jones proteins has not been extensively studied. Monoclonal immunoglobulin light chains are highly glycosylated $(13,36)$. The molar ratio between basic and neutral sugars $v s$ acid residues is not constant in myeloma immunoglobulins $(37,38)$, whereas this ratio is approximately $76: 24$ for normal immunoglobulins (39). In spite of advances in the analysis of glycoprotein-associated oligosaccharides (40), there are no reports in the literature about the relationship of tissue distribution to exposed carbohydrate residues.

The present results show that the relationship between basic and neutral sugars $v s$ acid residues of $\mathrm{BJ} s$ studied here is similar to the ratio found in normal immunoglobulins. Differences in the carbohydrate composition between BJ proteins have been observed by several laboratories and a straight correlation with possible pathogenesis has been suggested (41).

In our study, the galactose-rich BJ protein suffered intense endocytosis by asialoglycoreceptors, both at the hepatic and renal level. Interestingly, the patient who produced this protein developed severe kidney disease and had renal insufficiency resulting in death. In addition, the sialic acid-rich $\mathrm{BJ}$ protein obtained from another patient presented a smaller amount of galactose residues in com- parison to BJg. Clinical intervention led to a successful treatment, with survival without renal failure in the follow-up. Covering of galactose residues by sialic acid residues could be the mechanism implied in mild

Table 1 - Carbohydrate composition of the two Bence Jones proteins used in the present study.

Data are reported as $\mu \mathrm{g}$ carbohydrate/mg protein

\begin{tabular}{lrr}
\hline Carbohydrate & BJg & BJs \\
\hline Total & 37.8 & 12.6 \\
Neutral & & \\
$\quad$ Galactose & 28.8 & 4.6 \\
$\quad$ Mannose & 0.2 & 1.0 \\
$\quad$ Fucose & 0.2 & 0.5 \\
Basic & & \\
$\quad$ Glucosamine & 8.3 & 1.7 \\
Acidic & & \\
$\quad$ Sialic acid & 0.3 & 4.8
\end{tabular}

Table 2 - Hepatic distribution of Bence Jones proteins before $(\mathrm{BJg}, \mathrm{BJs})$ and after metaperiodate oxidation $\left(B J g_{m}, B J s_{m}\right)$.

Data are reported as median (25-75\% percentiles). Kruskal-Wallis method: $P<0.001$. Dunn's test: BJg vs $\mathrm{BJs}, \mathrm{BJg}$ vs $\mathrm{BJ} g_{m}, \mathrm{BJ} \mathrm{g}_{m}$ vs $\mathrm{BJ} s_{m}$ and $\mathrm{BJs}$ vs $B J s_{m}:{ }^{*} P<0.05$. Five animals in each group.

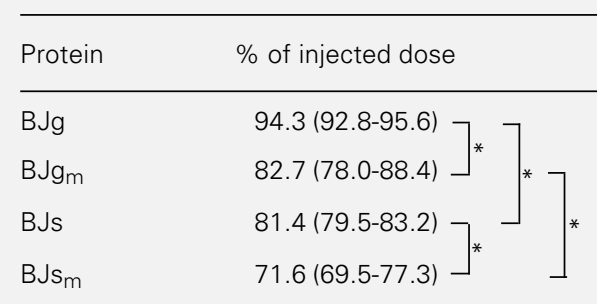

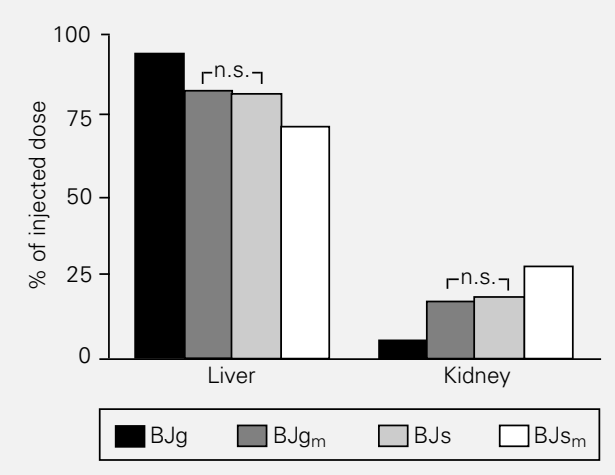

Figure 2 - Liver and renal uptake of Bence Jones proteins as native proteins (BJg and $\mathrm{BJs}$ ) and after metaperiodate oxidation ( $\mathrm{BJgm}$ and $\mathrm{BJ} \mathrm{s}_{\mathrm{m}}$ ). BJg: Bence Jones protein rich in galactose; BJs: Bence Jones protein rich in sialic acid. n.s., Not significant. 
Table 3 - Renal distribution of Bence Jones proteins before $(\mathrm{BJg}, \mathrm{BJs})$ and after metaperiodate oxidation (BJgm,$\left.B J s_{m}\right)$.

Data are reported as median (25-75\% percentiles) Kruskal-Wallis method: $P<0.001$. Dunn's test: BJg vs $\mathrm{BJs}, \mathrm{BJg}$ vs $\mathrm{BJg} \mathrm{g}_{m}, \mathrm{BJg} \mathrm{g}_{m}$ vs $\mathrm{BJs} \mathrm{s}_{m}$ and $\mathrm{BJs}$ vs $B J s_{m}:{ }^{*} P<0.05$. Five animals in each group.

\begin{tabular}{|c|c|}
\hline Protein & $\%$ of injected dose \\
\hline BJg & $5.7(4.4-7.3)$ \\
\hline$B J g_{m}$ & $17.3(11.6-24.7)\rfloor^{*} \mid * \neg$ \\
\hline BJs & $\left.18.6(16.8-20.5)\rceil_{*}\right\rfloor *$ \\
\hline $\mathrm{BJ} \mathrm{s}_{\mathrm{m}}$ & $28.4(22.8-30.6)$ \\
\hline
\end{tabular}

pathogenicity, causing a reduced uptake of this protein either by liver or kidney cells. Two different factors should be considered, i.e., tissue distribution and uptake. We found a marked distribution of BJg protein at the hepatic level, presumably related to galactose residues and recognition by specific receptors for asialoglycoproteins and consequently a reduced renal uptake (see Ref. 22 for a review). At the hepatic level there was a positive correlation between distribution and tissue uptake, while at the renal level the distribution was complementary. On the basis of the total amount in the kidney, it appears that renal uptake and catabolism of Bence Jones proteins is mainly the result of an efficient endocytic apparatus of proximal tubular cells. Pathogenicity may be directly related to the recognition by specific receptors, providing an efficient internalization by liver and kidney cells and consequently intracellular effects. In our experiments, carbohydrate oxidation was associated with a significant reduction of liver uptake of both proteins. Increased kidney uptake was probably a result of decreased hepatic accumulation. At the renal level we cannot assume that increased protein load shown by scintigraphy is associated with increased tissue uptake because low molecular weight proteins can be cleared by urinary excretion. An important role of carbohydrate residues in the interaction of BJ proteins with TammHorsfall proteins has been previously shown (42), and this favors kidney obstruction. These authors observed that cast formation and tubular obstruction were associated with sialic acid residues of Tamm-Horsfall proteins secreted in the tubular lumen by Henle loop cells. Colchicine treatment prevented cast formation by modifying the biosynthesis of Tamm-Horsfall proteins secreted without sialic acid under these conditions.

Furthermore, mannose residues also seem to play an important role in endocytosis since we observed a significant reduction in hepatic distribution and uptake after deglycosylation. Mannose recognition was probably mediated by specific receptors in hepatic and kidney cells as shown previously by other investigators who observed that the endocytosis of plasminogen-activating factor was mediated by mannose receptors on liver endothelium and by galactose receptors on parenchymal cells (23). Plasminogen-activating factor endocytosis was shown to be greater in endothelial cells (43), but it was practically absent in Kupffer cells. In a study using mannose covalently attached to albumin, a positive correlation between density of mannose residues of albumin and endocytic rate by non-parenchymal liver cells was demonstrated (44). Many investigators have studied the role of carbohydrate composition in liver cell endocytosis and observed that similar effects induced by deglycosylation could be obtained by removal of galactose residues.

In conclusion, we demonstrated a correlation between the carbohydrate content of Bence Jones proteins and their tissue distribution in a scintigraphic study. This procedure may be useful for other radiochemicals and could contribute to the elucidation of the mechanism of other diseases. Indeed, labelling with ${ }^{99 \mathrm{~m}} \mathrm{Tc}$ provided high accuracy and efficiency and permitted noninvasive dynamic studies. 


\section{References}

1. Sinclair D, Dagg JH, Smith JG \& Stott DI (1986). The incidence and possible relevance of Bence-Jones protein in the sera of patients with multiple myeloma. British Journal of Haematology, 62: 689-694.

2. Kyle RA (1983). Long term survival in multiple myeloma. New England Journal of Medicine, 10: 314-316.

3. Jones HB (1848). On a new substance occurring in the urine of a patient with "mollities ossium". Philosophical Transactions of the Royal Society of London, 139: 55-62.

4. Galton DAG \& Peto R (1973). Report on the first myelomatosis trial. British Journal of Haematology, 24: 123-139.

5. Constanza DJ \& Smoller M (1963). Multiple myeloma with the Fanconi syndrome: study of a case with electron microscopy of the kidney. American Journal of Medicine, 34: 125-133.

6. Finkel PN, Kronenberg K, Pesce AJ, Pollak VE \& Pirani CL (1973). Adult Fanconi syndrome amyloidosis and marked kappalight chain proteinuria. Nephron, 10: 1-24.

7. Short IA \& Smith JP (1959). Myelomatosis associated with glycosuria and aminoaciduria. Scotland Medical Journal, 4: 89-93.

8. Cohen DJ, Sherman WH, Osserman EF \& Appel GB (1984). Acute renal failure in patients with multiple myeloma. American Journal of Medicine, 76: 247-256.

9. Clyne DH, Brendstrup L, First MR, Pesce AJ, Finkel PN, Pollak VE \& Pirani CL (1974). Renal effects of intraperitoneal kappa chain injection. Laboratory Investigation, 31: 131-142.

10. Falconer-Smith JF, Hegan RI, Esnouf MP \& Ross BD (1979). Characteristics of renal handling of human immunoglobulin light chain by the perfused rat kidney. Clinical Science, 57: 113-120.

11. Koss MN, Pirani CL \& Osserman EF (1976). Experimental Bence Jones cast nephropathy. Laboratory Investigation, 34: 579-591.

12. Wochner RD, Strober $W \&$ Waldmann $T A$ (1967). The role of the kidney in the metabolism of Bence Jones proteins and immunoglobulin fragments. Journal of Experimental Medicine, 126: 207-220.

13. Kobata A (1990). Function and pathology of the sugar chains of human immunoglobulin G. Glycobiology, 1: 5-8.

14. Schmid SL (1992). The mechanism of receptor-mediated endocytosis: more questions than answers. Bioessays, 14: 589596.
15. Berg T, Gjoen T \& Bakke O (1995). Physiological functions of endosomal proteolysis. Biochemical Journal, 307: 313-326.

16. Bradbury NA \& Bridges RJ (1994). Role of membrane trafficking in plasma membrane solute transport. American Journal of Physiology, 267: C1-C24.

17. Strader $C D$, Fong $T M$, Tota MR, Underwood D \& Dixon RA (1994). Structure and function of $\mathrm{G}$ protein-coupled receptors. Annual Review of Biochemistry, 63: 101132.

18. Nuoffer C \& Balch WE (1994). GTPases: multifactorial molecular switches regulating vesicular traffic. Annual Review of Biochemistry, 63: 949-990.

19. Drickamer K (1987). Membrane receptors that mediate glycoprotein endocytosis: structure and biosynthesis. Kidney International, 32 (Suppl): S167-S180.

20. Kamimoto $Y$, Tanabe D, Tashiro S, Hiraoka T \& Miyauchi $Y$ (1994). Changes in receptor-mediated endocytosis in liver sinusoidal cells after partial hepatectomy in the rat. Liver, 14: 141-147.

21. Yoshioka T, Yamamoto $K$, Kobashi $H$, Tomita M \& Tsuji T (1994). Receptor-mediated endocytosis of chemically modified albumins by sinusoidal endothelial cells and Kupffer cells in rat and human liver. Liver, 14: 129-137.

22. Ashwell G \& Harford J (1982). Carbohydrate specific receptors of the liver. Annual Review of Biochemistry, 51: 531554.

23. Smedsrod $B$, Einarsson $M$ \& Pertoft $H$ (1988). Tissue plasminogen activator is endocytosed by mannose and galactose receptors of rat liver cells. Thrombosis and Haemostasis, 59: 480-484.

24. Prado MJBA, Nicastri AL, Leo $P$, Uchino E, Sesso A, Marcondes M \& Prado EBA (1993). Nephrotoxicity of human Bence Jones protein in rats: proteinuria and enzymuria profile. Brazilian Journal of Medical and Biological Research, 26: 633638.

25. Laemmli UK (1970). Cleavage of structural proteins during the assembly of the head of bacteriophage T4. Nature, 227: 680-685.

26. Grabar P \& Williams CA (1953). Méthode permettant l'étude conjuguée des proprietés électrophorétiques et immunochimiques d'un mélange de protéines. Application au sérum sanguin. Biochimica et Biophysica Acta, 10: 193-194.
27. Svennerholm L (1957). Quantitative estimation of sialic acids. A colorimetric resorcinol-hydrochloric acid method. Biochimica et Biophysica Acta, 24: 604-611.

28. Spiro RG (1966). Analysis of sugars found in glycoproteins. Methods in Enzymology, 8: 3-26.

29. Trevelyan WE, Procter DP \& Harrison JS (1950). Detection of sugars on paper chromatograms. Nature, 166: 444-445.

30. Spiro RG (1966). Characterization of carbohydrate units of glycoproteins. Methods in Enzymology, 8: 26-52.

31. Aspinall GO \& Ferrier RJ (1957). A spectrophotometric method for the determination of periodate consumed during the oxidation of carbohydrates. Chemical Industry, 7: 1216 .

32. Thakur ML, Defulvio J, Park CH, Damjanov A, Yaghsezian $H$, Jungkind D, Epstein A \& McAfee JG (1991). Technetium-99m-labelled proteins for imaging inflammatory foci. Nuclear Medicine and Biology, 18: 605-612.

33. Oyen WJG, Claessens RAMJ, Van Horn JR, Van der Meer JWM \& Corstens FHM (1990). Scintigraphic detection of bone and joint infections with indium-111-labelled nonspecific polyclonal human immunoglobulin G. Journal of Nuclear Medicine, 31: 403-412.

34. Pasquali $S$, Zucchelli $P$, Casanova S, Cagnoli L, Confalonieri R, Pozzi C, Banfi G, Lupo A \& Bertani T (1987). Renal histological lesions and clinical syndromes in multiple myeloma. Clinical Nephrology, 27: 222-228.

35. Ganeval D, Lacour B, Chopin N \& Grunfeld JP (1990). Proteinuria in multiple myeloma and related diseases. American Journal of Nephrology, 10: 58-62.

36. Ohkura $T$, Isobe $T$, Yamashita $K$ \& Kobata A (1985). Structures of the carbohydrate moieties of two monoclonal human lambda-type immunoglobulin light chains. Biochemistry, 24: 503-508

37. Mizuochi T, Taniguchi T, Shimizu A \& Kobata A (1982). Structural and numerical variations of carbohydrate moiety of immunoglobulin G. Journal of Immunology, 129: 2016-2020.

38. Kobata A, Mizuochi T, Endo T \& Furukawa K (1989). Function and pathology of the sugar chains of human immunoglobulin G. Ciba Foundation Symposium, 145: 224235 
39. Harada H, Kamei M, Tokumoto Y, Yui S, Koyama F, Kochibe N, Endo T \& Kobata A (1987). Systemic fractionation of oligosaccharides of human IgG by serial affinity chromatography on immobilized lectin columns. Analytical Biochemistry, 164: 374-381.

40. Dwek RA, Edge CJ, Harvey DJ, Wormald MR \& Parekh RB (1993). Analysis of glycoprotein-associated oligosaccharides. Annual Review of Biochemistry, 62: 65100.
41. Wasserman RL \& Capra JD (1977). Immunoglobulins. In: Horowitz MI \& Pigman W (Editors), The Glycoconjugates. Academic Press, London.

42. Sanders PW \& Booker BB (1992). Pathobiology of cast nephropathy from human Bence-Jones proteins. Journal of Clinical Investigation, 89: 630-639.

43. Einarsson M, Smedsrod B \& Pertoft $H$ (1988). Uptake and degradation of tissue plasminogen activator in rat liver. Thrombosis and Haemostasis, 59: 474-479.
44. Jansen RW, Molema G, Ching TL, Oosting R, Harms G, Moolenaar F, Hardonk MJ \& Meijer DKF (1991). Hepatic endocytosis of various types of mannose-terminated albumins. What is important, sugar recognition, net charge, or the combination of these features? Journal of Biological Chemistry, 266: 3343-3348. 